\title{
On the Implicit Ideological and Political Education Ecology of Colleges and Universities in "Micro Era"
}

\author{
Yanxu Zhao \\ School of Chemistry \& Chemical Engineering \\ China West Normal University \\ Nanchong City, Sichuan Province, China \\ 117533462@qq.com
}

\begin{abstract}
Micro era has brought huge impacts on implicit ideological and political education environment of colleges and universities. The carrier has transformed from the material and cultural resources in the campus to internet "micro era". This change is mobile and diffusive with features of equal interaction and circle. Thorough study and analysis of these characteristics conforms to the operation mechanism of implicit ideological and political education. It can strengthen micro-era advantages, thus increasing the effectiveness of implicit ideological and political education of colleges and universities.
\end{abstract}

Keywords-micro era; micro platform; ideological and political education; ecology

\section{INTRODUCTION}

The development of digital technology is potentially changing the ecological environment of implicit ideological and political education in colleges and universities. The carrier has transformed from the material and cultural resources in the campus to internet "micro era". Based on the digital technology of information, the "Micro Era" is a new communication era. With the aid of digital communication technology and multiple forms of audio, video, text and images, its communication has the features of real time, interaction and high efficiency through new, mobile and convenient display terminal. [1]Micro-blog, WeChat, micro evaluation and micro media, which are called micro platform hereinafter, are representatives of this era. Having inherited the characteristics of the network environment, such as virtuality, real-time, openness, and so on, the micro platform belongs to the network platform. It is a fertile soil for the implementation of implicit ideological and political education. However, universities still have a wait-andsee and ignoring attitude towards the study of these new things. The study on characteristics and mechanisms of the implicit ideological and political education in colleges and universities are obviously inadequate. The arrival of "micro era" is overwhelming. We can only make it more effective for the implicit ideological and political education in colleges and universities when we think carefully and make effective use of it.

\section{NEW CHANGE OF IMPLICIT IDEOLOGICAL AND POLITICAL EDUCATION ENVIRONMENT OF COLLEGES AND UNIVERSITIES}

\section{A. Research environment migration.}

In recent years, much attention has been paid to implicit ideological and political education. The academic circles have made a great deal of research on its definition, connotation, characteristics, operation mechanism and practice ways, mainly from the resource theory, practice theory, curriculum theory, methodology and other angles. After a series of carding, it is found that the ideological and political education environment in colleges and universities is mostly thought of two forms: material form and spiritual form. The former mainly refers to the ideological and political education intention of school buildings, ecological environment, classroom settings and so on; the latter refers to the school campus cultural environment, historical tradition, spirit, campus characteristic with projection of the ideological and political education concept, as well as the school members' common goal and value system, moral emotion and behavior. [3]With the further development of digital technology, the new media era has occupied the highland of ideological and cultural communication. In particular, the invention of integrated multi-functional, new and convenient mobile display terminals like IPad, all-in-one tablet PCs and mobile phones has focused people's attention on new media tools. Mobile phones and other communication tools has become the "third party" between lovers, the "resistance device" of parent-child time and the "killer" on the road. People's ideological activities depend more and more on the network environment. According to the latest statistics released by Chinese University Students Online, the number of internet users among college students is the largest among all Internet users in China. Their use of the internet to learn, live and play is very common. It is also common to use the internet to communicate ideas, express personal values and expand relationships. [2]The implicit ideological and political education in colleges and universities has extended to the "micro era".

\section{B. High dependence on new technologies.}

With the further development of digital technology, the mobile phone, as the representative of the communication tool, 
integrates multimedia functions and provides a convenient and mobile display terminal. It is transformed from a simple communication tool into a platform for comprehensive information collection, dissemination and entertainment. The use of mobile phones by college students has also changed. A word is in fashion now, "a cell phone in hand, go anywhere without fear." College students are avant-garde progressive and very sensitive to new things and technologies. They can soon master new technologies of the "micro era", brush micro-blog and WeChat through the display terminal, make micro video on their own and post micro comments. Under such circumstances, their ideas, ways of thinking and values are undergoing profound changes.

\section{THE ECOLOGICAL CHARACTERISTICS OF IMPLICIT IDEOLOGICAL AND POLITICAL EDUCATION IN COLLEGES AND UNIVERSITIES IN "MICRO ERA"}

The essence of "micro era" is the era triggered by the rapid development of information technology. The ecological environment of the traditional ideological and political education in colleges and universities has inevitably been impacted by the "micro era". With its own advantages, it has realized the quick flow of information and the free expression of thought. Deep analysis shows that the ideological and political education ecology of colleges and universities has the following characteristics in the background of "micro era".

\section{A. Mobility.}

Being different from the traditional environment of conscious design of the subject, in the "micro era", the development of the ideological and political education in colleges and universities is more relaxed. For example, the humanistic environment of college campus is a historical accumulation, and the projected educational intention is very clear. "The mobility of "micro era" is mainly embodied in the complexity of information channels and the randomness of information source switching. When the educational object concerns the information provided by the current micro platform, the ongoing behavior can be stopped at any time due to a topic change or other causes. Thus, the attached implicit ideological and political education content is changed.

\section{B. Diffusivity.}

In "the six degree separation theory" proposed by Milgram, an American psychologist, there will be no more than six people between you and any stranger. That is to say, you can recognize any stranger through at most six people. This helps to understand how the people quickly spread information by clicking on the mouse in "micro era". To sum up, the diffusivity of the micro era is mainly manifested in three ways. First, it inherits the propagation characteristics of the network, high efficiency and real time. Second, it has self-media features. The public can conveniently produce, transport and consume information through the WeChat, micro-blog and other micro platform, which accelerates the proliferation of information. Third, the micro platform information is fragmented. Publishing information on a micro platform is limited by word count. For example, Sina micro-blog set the number of words only 140 Chinese characters. This restriction, on the one hand, makes the content slightly shorter, helping to reduce propagation delays. On the other hand, when people express their opinions, they must refine and concentrate the information, and pass on the most core and the most essential information as much as possible, which will help to enjoy the fast-food culture consumption in the fast-paced life.

\section{Equal interaction}

"Micro era" breaks the boundaries between the communicators and receivers of information. A communicator can be a communicator at this time and at that time is the receiver. The two roles overlap. In the process of information communication, "centralization" is gradually realized, so as to realize the full communication, interaction and dialogue of information, and set up a new interactive space of equality. It helps college teachers and students to start exchanges and interaction without identity base.

\section{Circle nature}

In the traditional model, students in colleges and universities generally exchange ideas with class, community, dormitory and fellow townsman. But the emergence of micro platform makes the group with common interest, common aesthetic and common values spent very little time to find their own circle of communication and quickly integrate into it. Field study found that a college student has 5 QQ group and WeChat group on average. This virtual communication circle has become an important channel for their access to information sources.

\section{EFFECTIVELY PROMOTE THE EDUCATIONAL FUNCTION OF THE IMPLICIT IDEOLOGICAL AND POLITICAL EDUCATION ACCORDING TO THE CHARACTERISTICS OF THE MICRO ERA}

The coming of "micro era" has brought a great "liberation" to people's ideological communication, political, economic and social life. At the same time, the dissemination of false information, garbage information, public opinion violence, network rumors and network fraud also exist in this virtual world of micro platform. How to seize the essence of new things and the law of development, and make use of micro platform to effectively promote the educational function of implicit ideological and political education? This is the new direction and new challenge of ideological and political education work in the new period.

\section{A. Enhanced micro platform construction.}

The major living and studying place for college students is the campus. Therefore, we should fully understand the university students concern, care and favorites, enrich the content of the platform, and enhance the construction of campus micro platform to attract students' eyes. In general, college students use multiple micro platforms every day to understand the information they care about. In the end, which micro platform should be chosen to pay attention to depends on if it is close to the needs of students, close to their learning and life. Therefore, a few points should be paid attention to during the construction of the platform. First, channels could be set up in the micro platform to feedback sensitive events on campus, 
and discuss and dredge the students' school-loving complex. Second, the current hot topics and news events could be set up to let the students know the international and domestic situation, the development of the domestic economy and social life, and to cultivate the students' political awareness and patriotic consciousness. Third, professional push-hand could be organized to dynamically update and maintain micro platform and constantly enhance the platform influence, so that students could consciously follow. Many colleges and universities treat campus public opinion and network politics in form. The lack of professional maintenance team has put the micro platform into an embarrassing state of silence.

\section{B. Change pushing communication style.}

It is known that the existing campus network is mainly based on the general situation of the school, professional settings, daily transaction processes, news notifications, etc., which is a one-way information push model. The micro platform is obviously different. It is more of a self-media model. Therefore, the authoritative mode of information publication should be changed to realize equal communication. Teachers and students are required to enjoy equal right to speak on this platform. College students' personal opinions and personal feelings should be paid more attention to, given more understanding and more analysis, so as to form their own original and correct ideas. The advantages of implicit ideological and political education should be fully brought out to interact thinking deeply with equal attitude. On the other hand, the malicious rumor spreading among college students should be criticized and educated. Investigate and restore the truth of the event, publish the result quickly and dredge the network public opinion instead of simply deleting the titles and ID and blocking sensitive information.

\section{Build a long-term mechanism leading by micro platform thinking.}

Micro era is the inevitable trend of information technology development in the future. With the increasing variety of micro platforms, it is necessary to constantly explore the long-term mechanism leading by micro platform thinking and promote the healthy development of the implicit ideological and political education in the micro era. First, construct propagation and guidance mechanism of micro platform. Colleges and universities have a relatively fixed physical space, higher quality of the object of education, the desire to strive for goals clearly and the motivation to make friends and get information. These are the essential characteristics of implicit ideological and political education. It is suitable for Bai Xianliang's implicit ideological and political education needs guidance mechanism in his Study on Basic Theory of Implicit Ideological and Political Education.[4]Information communication needs, cultural and entertainment needs, as well as the realization of the ideal of life and the goal of struggle could be obtained through the micro platform as the driving force to construct dissemination and guidance mechanism. Do a good job of continuing to spread the positive energy of ideological and cultural content and monitoring the bad information guidance work within the circle of micro platform to provide sustained external spiritual power support to educational objects. Second, construct feedback mechanism of micro platform. Micro platform, also known as the selfmedia platform, the monitoring of which is very weak, has become the hotbed of exposing the "secret" event. As Marx once pointed out, "All secrets are alluring." Micro platform often becomes the platform if issuing latest personal state, sharing "explosion news" and hot events. Driven by curiosity, people tend to follow, send and re-spread continuously, which easily triggered network "Butterfly Effect" and made people impossible to guard against. Therefore, it is necessary to build a micro platform feedback mechanism within the controllable range of universities. Large data cloud computing technology could be used to collect suspicious speech, make judgment and do public opinion guidance. Third, construct coordination and integration mechanism of micro platform. As a new thing, micro platform is a double-edged sword. On the one hand, it strengthens interpersonal interaction and improves the efficiency of information diffusion, which is conducive to the political, economic and social development. On the other hand, the spread of public opinion is likely to cause social panic and mass incidents, which is not conducive to social stability, unity and development. But the pace of scientific and technological progress is not controlled by human will. We can only adapt to the trend and keep pace with the development of new things, so that it can serve mankind better. Therefore, the Party and political departments of universities should attach great importance and cooperate with other departments and units in the school to deal with the impact of the micro era. Regulatory measures for micro platforms should be developed so that the users could express personal ideas and opinions calmly and rationally, are responsible for their own speech, and can not take the micro platform as an outlet for venting personal emotions. For example, when applying for micro-blog or WeChat group, the relevant legal requirements and group rules should be announced in these circles to form a warning and self-education atmosphere.

\section{CONCLUSION}

The arrival of "micro era" has accelerated the transformation of the "information sharing" model of the internet to "thought sharing" model. This transformation has highlighted its unique characteristics. Colleges and universities should make good use of it and shoulder the responsibility of college students' ideological, moral and political guidance to create a new situation of ideological and political education in "micro era".

\section{REFERENCES}

[1] Lin Qun, Rationally Facing the "Micro Era" of Communication". Research on Ideological and Political Work (Learning Digest), 2010.3 (In Chinese)

[2] Luo Yuting, Construction of Long Term Mechanism of Ideological and Political Education in Colleges and Universities under the New Situation. Theoretical Front in Higher Education, 2008.10 (In Chinese)

[3] Fang Fei, Zhang Li, Liu Xiaojie, A Summary of Implicit Ideological and Political Education Research. Journal of Qingdao Administration College, 2008.7 (In Chinese)

[4] Bai Xianliang, Study on Basic Theory of Implicit Ideological and Political Education[M]. Beijing: People's Press, 2013:35.2013:233. (In Chinese) 